\author{
Marcia Tiburi \\ Universidade Presbiteriana Mackenzie
}

\title{
Diadorim: biopolítica e gênero na metafísica do Sertão
}

\begin{abstract}
Resumo: Diadorim é a emblemática personagem da obra de Guimarães Rosa, avatar da donzela guerreira, símbolo de uma forte renúncia, que podemos afirmar feminista, aquela que se faz na negação do feminino para viver na liberdade do além-do-sexo. A análise de tal personagem permite avaliar a relação entre corpo e poder como fundamento da história conhecida da dominação de gênero. O objetivo deste trabalho é uma leitura feminista que permita investigar a dupla banda da sexualidade que envolve a figura de Diadorim. Homem e vivo enquanto vestido, mulher e morta no advento de sua nudez, Diadorim fará parte de uma história arquetípica, do topos da mulher/morta. Essa mulher morta é, assim, também a "mera vida" ou a "vida nua" que comparece na análise biopolítica contemporânea. O cruzamento de feminismo e biopolítica é o método de leitura dessa obra. Ele nos fará ver que a função da textualidade no patriarcado é tanto gozar sobre o corpo morto de uma mulher quanto devolvêla à sua suposta natureza doméstica e antipolíica.
\end{abstract}

Palovras-chave: feminismo; Diadorim; biopolítica; Sertão.

Copyright () 2013 by Revista Estudos Feministas.

\footnotetext{
“... a gente quer passar um rio a nado, e passa; mas vai dar na outra banda é num ponto muito mais embaixo, bem diverso do que em primeiro se pensou." João Guimarães Rosa, Grande Sertão: Veredas.
}

\section{Motivos para matar Diadorim}

A questão posta por Nicole Loraux em seu livro Façons tragiques de tuer une femme (1985) acerca das modalidades da morte de mulheres nas tragédias gregas serve-nos neste momento para pensar a morte de Diadorim no desfecho semifinal de Grande Sertão: Veredas, de João Guimarães Rosa. A morte das mulheres, segundo a análise de Loraux, se torna visível pela fala de homens. Inscritas no discurso dos homens e para seu deleite estético, essas mortes dizem tudo sobre a vida das mulheres.

Louraux declara que na tragédia, por seu evidente caráter textual, tudo se passa pelas palavras e, sobretudo, a morte. Morte que deve "começar por ser dita, por ser 
1 Nicole LORAUX, 1985, p. 9

${ }^{2}$ LORAUX, 1985, p. 11

\footnotetext{
${ }^{3}$ Do cinema podemos falar de $A$ Dama do Lago, de Robert Montgomery (1947), Fale com ela, de Pedro Almodovar (2002), Revolutionary Road, de Sam Mendes (2008), Inspector Bellamy, de Claude Chabrol (2009), e do coreano Poetry, de Lee ChangDong (2010). Nas artes visuais abundam as representações de mulheres mortas. Mas é curioso que as próprias mulheres trabaIhem com o motivo. De Artemísia Gentileschi (1593-1563) a Cindy Sherman, Janaína Tschape, Anuschka Blommers, Chantal Michel o topos se repete. O que coloca em questão o motivo pelo qual o tema não teria sido superado pelas próprias mulheres.

${ }^{4}$ Edgar Allan POE, 1960, p. 506

${ }^{5}$ Eva Alterman BLAY, 2008, p. 23.
}

entendida, por ser imaginada - visão nascida das palavras e sustentada nos olhos"). ${ }^{1}$ Interpretando a tragédia como um evento sonoro, como a audição de uma fina leitura, não apenas um espetáculo, como processo de compreensão discursiva e não apenas imagem, Loraux leva a atenção para o caráter literário e simbólico dessas mortes. Assim, a morte de Diadorim, apresentada pelo discurso de Riobaldo, parece ter o mesmo sentido que a morte das mulheres na tragédia. Também ela é a bela morte de uma mulher, dita e feita no discurso de um homem com o "benefício imaginário"2 que lhe é próprio.

Em que pese a diferença de cada uma das mortes dessas mulheres, todas levam a pensar no estatuto patriarcal do imaginário presente nos textos. O que une a tragédia grega ao romance roseano é o mesmo motivo sobre o qual devemos prestar atenção: a morte narrada é sempre a morte de uma mulher. Há, na interpretação da filósofa helenista, um modo de morrer masculino e um modo de morrer feminino que determinam papéis de gênero. Certo é que a morte dos homens também é narrada, mas enquanto ela os faz heróis na transcendência da mera vida, a morte das mulheres não as torna heroínas, antes serve para recolocá-las em seu lugar, a de ser doméstico a viver na penumbra da casa. Devolvêlas ao lugar de onde saíram, à sua "natureza de mulher", eis o papel da morte na tragédia de um modo geral, segundo a visão de Loraux, e, a meu ver, da morte de Diadorim.

Garantia de sucesso literário (e hoje de tantas obras do cinema e de artes visuais ${ }^{3}$ ), como se pode ver na velha declaração de Edgar Allan Poe de que "a morte de uma mulher é o motivo mais poético de mundo", ${ }^{4}$ é o que temos em Grande Sertão: Veredas. A velha tradição textual realizando sua fenomenal função de assassinato na intenção do gozo estético. Diadorim "morta", momento apoteótico da narrativa, é o desfecho da lei à qual Diadorim está abandonada. A pergunta simples a ser feita diz respeito à analogia entre texto e lei: se uma mulher pode ser morta na literatura de ficção (ou no cinema, ou nas artes visuais), se sua morte é bela e esteticamente viável, por que não seria politicamente aceitável? Toda estética tem sua política, e vice-versa. Se a escritura tem o estatuto de lei sendo ponte entre a realidade e a ficção, a fartura da temática da "mulher morta" em todos os campos das artes não é simplesmente inofensiva no contexto da "constante cultural" que é o assassinato de mulheres. ${ }^{5}$ Há uma solidariedade entre realidade e imaginário que não deve passar despercebida. Se o topos da mulher morta é uma constante imagética, estética e poética, não haverá uma ética e, mais, uma política que lhe subjaz? 
${ }^{6}$ Michel FOUCAULT, 1999, p. 133. ${ }^{7}$ Diadorim é personagem multifacetado. Urobórica encarnação da dialética, da ambiguidade, do princípio da duplicidade que organiza o mundo na unidade tão impossível quanto almejada, encarnação da donzela guerreira da crise do paradigma sexual $e$ do amor platônico a um só tempo. Figura da androginia e do que Mircea Eliade chamou "o mistério da totalidade" (Mircea ELIADE, 1999, p. 77), em que essência e aparência, masculino e feminino, homem e mulher, bem e mal, anjo e demônio, se associam como num ancestral ritmo de explicação do mundo, Diadorim realiza sua morte num momento muito especial e significativo: junto da morte de Hermógenes, infinitamente mais humano e menos divino do que Riobaldo, o princípio demoníaco explícito, que também a feriu e que, como seu negativo, é o outro lado que se associa ao mesmo na maleável Banda de Moebius, a leminiscata (Francis UTÉZA, 1994, p. 422), que, finalizando o romance, também nos sugere um método de leitura em que é preciso voltar sempre atrás, numa espécie de ritornello para entender 0 que aconteceu. Riobaldo é, nesta história, o inventor e o testemunho do laço do amor, da racionalidade, da civilidade, da linguagem e que, por meio de Diadorim - ela é meio talvez o que Riobaldo chama "homem humano" e "travessia" ao final do romance, mas também é fim segundo o primeiro final, $o$ semifinal do romance (ROSA 1986, p. 531)-é a contraposição direta a Hermógenes, personagem que simboliza a barbárie, a imoralidade, o mal maligno que destrói sem repor.

${ }^{8}$ Jacques DERRIDA, 2006, p. 125

9 DERRIDA, 2006, p. 21.
Afirmar que homens escreveram sobre mulheres mortas com intenção de gozo estético não é um exagero. A semelhança entre discurso e violência não é, no terreno da arte e da literatura, da ordem da mera coincidência. Trata-se, neste momento, de pensar a questão biopolítica no sentido do "investimento sobre o corpo vivo, sua valorização e gestão distributiva de suas forças", segundo a definição de Foucault ${ }^{6}$ da qual o discurso e a imagem são as mais naturais das armas.

\section{Escamotear pelo discurso}

A força do topos não elimina a diferença entre as mortas gregas, princesas e rainhas, e a cangaceira do sertão mineiro. As gregas morriam na cama, suicidavam-se por seus maridos ou eram sacrificadas por motivos religiosos. Acrescento um detalhe a meu ver importante. Loraux se atém às personagens trágicas. Não importa, por exemplo, que uma mulher morra no parto. Fato que não configurava tragédia, pois vazio de tensão política. Simples atividade orgânica, própria da vida das mulheres por oposição à vida dos homens. Fato fundamental é que nenhuma das gregas jamais morreu em combate como Diadorim. No entanto, permanece a simetria dos motivos, na maneira com que morre Diadorim, ainda que em luta de morte com Hermógenes, ${ }^{7}$ ela não sai em posição de destaque como vencedora ou como heroína. O fato de ter morrido enquanto matava o temível Hermógenes é apagado no deslumbramento diante de seu corpo feito cadáver.

Loraux fala de "benefício imaginário" que tais mortes ditas causam a um público de cidadãos. Perguntemos, então, se as mulheres serviriam de matéria à imaginação mórbida dos homens. O que nos mostra a morte de Diadorim? Lida com base no gozo estético que só uma cultura patriarcal pode sustentar, ela mostra pouco. Prazer estético e erótico também não dizem muito, além de que o patriarcado seja perverso e que a questão se esgote na explicação por "coisa de homem". A hipótese do "logocentrismo" e do "falocentrismo", bem como do "fonocentrismo", 8 que definem o sentido de uma "violência da letra", pode nos levar mais longe na intenção de compreender o sentido do próprio texto.

Características da narração de Riobaldo, o falo-logofonocentrismo vem garantir o caráter prescritivo de uma fala que ao se pronunciar estabelece uma espécie de "lei natural". ${ }^{9}$ Na forma de verdade inquestionável por sua simples apresentação é que aparece o corpo morto de Diadorim como uma espécie de emblema por meio do qual a "mulher" é finalmente marcada. Na posição de narrador romântico da morte de sua musa (aquela que o leva a 


\begin{abstract}
${ }^{10}$ A propósito, ver a dissertação de mestrado de Ellen Guillhen A morte de Ofélia nas águas: reflexos da personagem de Shakespeare na poesia simbolista brasileira (2008), na qual a autora analisa a sobrevivência da imagem de Ofélia morta nos poemas de Valentim de Magalhães, Cruze Sousa, Alphonsus de Guimaraens, Guerra Duval, Alceu Wamosy e outros. Ver também $o$ anexo com poemas ofélicos em diversas línguas (UNICAMP-IEL, 2008).

11 O material crítico sobre Ofélia é vasto. Na linha desta argumentação sugiro a leitura de "Ofélia morta: do discurso à imagem", de Marcia Tiburi (2008).

12 João Adolfo HANSEN, 2000, p. 131.
\end{abstract}

${ }^{13}$ HANSEN, 2000, p. 133.

${ }^{14}$ ROSA, 1986, p. 126 contar), Riobaldo é mais um dos representantes da necrofilia epistemológica que pesa sobre as mulheres. Necrofilia que se eleva à imagem e ao texto, que se alça à posição de escritura. E lei. Na cena da morte de Diadorim, temos a continuação histórica da condenação à morte dada na e pela ficção. Tragédia, romantismo e simbolismo unem-se no espetáculo da morte das mulhere ${ }^{10}$ das quais Ofélia, morta na água, é a grande musa. ${ }^{11}$ Diadorim, morrendo na seca do Sertão, deve ser o seu oposto complementar.

O corpo exposto de Diadorim é corpo marcado. Como emblema da duplicidade, Diadorim é duplo que mostra e esconde. Aparecendo como mulher e morta, ele desaparece como homem vivo. Mas não simplesmente, pois a "dia-lética" - própria ao nome de Diadorim - implica que o homem vivo é, em convenientes termos hegelianos, suprassumido na "mulher". Nesse sentido há uma significação ocultada que Riobaldo não pode ver. "Aquilo que Riobaldo toma como significação do nome não corresponde ao que o nome está designando no secreto, a significação ocultada da mulher". É o que nos diz, por exemplo, João Hansen, para depois concluir que "o nome 'Diadorim', assim, não só significa a si, na aparência enganosa, mas também a irrupção do duplo em Riobaldo: (não)-ser, ausência, mas também figuração de significação essencial, verdade". ${ }^{12}$ Ou seja, há algo que se mostra e algo que se oculta e as duas coisas acontecem ao mesmo tempo.

O que é ser homem/o que é ser mulher? É a pergunta que surge na forma de uma dupla banda diante da aparição de Diadorim como corpo de mulher morta. Neste ponto é preciso propor uma leitura que compreenda a função dessa morte no contexto de um par categorial: escamoteamento/revelação em que a questão da sexualidade vai bem mais longe do que a de um efeito "divertido" no qual a oposição entre sexo masculino e feminino seria "irrelevante". ${ }^{13}$ Certamente, estamos diante das questões metafísicas da oposição e da conjunção, como veremos adiante. Muito mais, estamos diante da exposição de um sério desejo homosexual que é confessado e justificado durante toda a narrativa de Riobaldo.

Se, de um lado, Riobaldo pode ficar na indecidibilidade edipiana, de outro, a morte de Diadorim oferece uma espécie de perdão heterossexual a Riobaldo, que até então se debatia com o seu "desejo encoberto", ${ }^{14} \mathrm{com}$ aquilo mesmo que

eu mesmo não entendia então o que aquilo era? Sei que sim. Mas não. E eu mesmo entender não queria. Acho que. Aquela meiguice, desigual que ele sabia esconder o mais de sempre. E em mim a vontade de chegar todo próximo, quase uma ânsia de sentir o

194 Estudos Feministas, Florianópolis, 21(1): 191-207, janeiro-abril/2013 
${ }^{15}$ ROSA, 1986, p. 125

16 ROSA, 1986, p. 78

17 TIBURI, 2010, p. 111

${ }^{18}$ Ver o artigo de Márcia Marque de Morais "Coração mistura amores: o desejo deslocado nas veredas do Grande Sertão" (2008). Nesse artigo, a autora enfrenta a questão do desejo remetendo ao fato de que Riobaldo só assume seu amor quando o percebe "encoberto de amizade" e retira, assim, a análise do moralismo com que muitas vezes foi tratada. cheiro do corpo dele, dos braços, que às vezes adivinhei intensamente - tentação dessa eu espairecia, aí rijo comigo renegava. ${ }^{15}$

Mesmo que se possa com isso dizer que, na verdade, a questão do amor entre os dois jagunços esteja para além da oposição entre os sexos, lançada no universo da metafísica, é um fato emblemático do texto que Diadorim feito mulher/morta redime Riobaldo de seu desejo, dos "vícios desencontrados", com o sacrifício daquele mesmo que ele desejou. De resto temos confirmada a lei do patriarcado: quem paga a conta do desejo masculino é o ser heterodenominado pelo patriarcado de "mulher".

É justamente, nesse sentido, que a posição romântica de Riobaldo, no viés de um falocentrismo, vem revelar o que importa em um primeiro momento. O caráter proibido - ainda que confesso - do desejo do narrador, que tinha representado até então um ganho crítico do personagem em relação à moral heterossexual, cai por terra no momento da exposição do corpo morto sacrificado. O que pretendo mostrar é que a morte de Diadorim surge como solução de Rosa para dar ganho de causa à tradição: pois que a figura de Diadorim mulher e morta (diremos de agora em diante apenas mulher/ morta) é o emblema que tanto vem revelar o desejo de um homem por uma mulher quanto vem "tapar" o desejo do homem por outro homem.

É o amor pela mulher/morta que, revelando um segredo, escamoteia ao mesmo tempo a homoafetividade de Riobaldo com a qual ele lutou até o fim, heterodenominando com a arma do discurso seu desejo como da ordem de algo "diabólico", um afeto "dum jeito condenado". ${ }^{16} \mathrm{Se}$ as mulheres tais como Maria Bonita ${ }^{17}$ teriam sido introduzidas no cangaço real para evitar quaquer desconfiança de homoerotismo, ${ }^{18}$ Diadorim - que não é mulher, lembremos, senão quando se revela seu corpo morto - acabaria tendo uma função dupla: enganar o cangaço de sua masculinidade absoluta, mas, por outro lado, levar o homoerotismo até uma tensão que culmina com uma espécie de sacrifício do objeto cujo caráter tentaremos desvendar. O homoerotismo (homosexualidade ou homoafetividade) aparece apenas para que possa ser negado. Uma revolução sexual em nome da homoafetividade se anuncia e é, no instante derradeiro, negada. Como que julgada durante todo o texto feito lei, ela é condenada enquanto, ao mesmo tempo, uma espécie de redenção heterosexual é alcançada com a imagem do corpo morto de Diadorim.

A negação da homosexualidade é paralela à armadilha antifeminista: a isca é o corpo de uma mulher que só pode aparecer como mulher enquanto morta. Ou de um homem que, ao ser morto, aparece como mulher. O corpo de 
19 Judith BUTLER, 2003, p. 8.

mulher morta é, nesse caso, o desfecho de uma lei a ser cumprida. O corpo de mulher parece para sempre subjugado ao destino - a uma lei ditada pelos homens. A lei que é o próprio patriarcado, do qual o texto é o lugar comum.

A revelação da mulher/morta é também a morte do objeto do desejo. Ela tem a função de liberar o desejo enquanto libera do desejo. Uma mulher morta é um tipo específico de objeto, a mulher em sua condição de objeto puro. Não mais passível de um ato sexual que implicaria a heterosexualidade a ser provada, é a prova mesma do triunfo da heterossexualidade que, tendo sido posta à prova durante todo o livro, não precisaria mais provar a si mesma, estaria desimcumbida de provar-se, livre do peso de provar-se. Assim, é o corpo morto de mulher que salva o jagunço de seu desejo heterosexual quando, ao mesmo tempo confirmando o prévio e autoafirmado amor homossexual, o livra de assumi-lo. De fato, é verdade que ao mesmo tempo que o libera da mulher, libera-o também do homem, enredando-o para sempre nessa mulher-homem, nesse homem-mulher. Libera-o do sexo lançando-o na sexualidade impossível, transformando, assim, a inação sexual em potência absoluta da sexualidade.

O amor sinuoso dos personagens é homossexual até render-se numa espécie de "heterossexualidade compulsória". ${ }^{19}$ Riobaldo recebe dessa morte a autorização para amar, mas apenas porque o objeto de seu amor foi desnudado em uma verdade que Ihe favorece. Assim ele ganha o amor enquanto é, ao mesmo tempo, logrado no desejo. Ao fim, o ganho é do sujeito patriarcal (sempre moral), e não do sujeito do desejo que seria finalmente liberto. $O$ amor não passa, nesse caso, da miséria moral autorizada contra o desejo em relação a um objeto proibido. A perda maior, no entanto, é do sujeito feito objeto do patriarcado: Diadorim surge como figura enganadora sendo lograda por sua própria morte ao não dispor de si mesma.

\section{Mera vida}

Diadorim, no entanto, pode nos levar ainda mais longe. Se ele se inscreve nesse curioso topos que é o da mulher/ morta, não se trata apenas do papel da morte para uma mulher (o de fazê-la voltar à casa), mas muito mais o papel da mulher o que está em jogo, e esse é o de morrer. Daí que Diadorim apareça como "mulher" apenas quando "morta". A morte, nesse caso, não é apenas um meio para que ela volte à casa, mas aquilo que lhe cabe enquanto mulher. Em outras palavras, não é, no caso de Diadorim, apenas uma mulher que é morta, mas, como precisamos ver, que alguém de quem não sabemos que seja mulher até o fim da leitura, só é mulher uma vez que morta, ou seja, simultaneamente 
${ }^{20}$ Giorgio AGAMBEN, 2002, p. 12. ${ }^{21}$ AGAMBEN, 2002, p. 16.

${ }^{22}$ ROSA, 1986, p. 21, grifos nossos.

${ }^{23}$ ROSA, 1986, p. 21, grifos nossos.

${ }^{24}$ Leonardo Vieira de ALMEIDA, 2011. Segundo o autor, "O emblema trágico se compõe a partir da tensão que se estabelece entre os símbolos que configuram a ordem da barbárie, a lei jagunça, e o corpo que não deixa de revelar e esconder os traços da philía". mulher e morta. Alguém que pretendia parecer homem, vestindo-se, agindo, falando como homem, surge como que "castigado" no ato mesmo de ser "devolvido" ou "abandonado" à sua natureza.

Diga-se de passagem, natureza morta, enquanto todas as demais personagens do livro de Rosa mantêm-se vivas, porquanto são emblemas de papéis femininos: moças casadoiras, prostitutas, adúlteras. A pergunta pelo motivo da morte de Diadorim é primeiramente banal e dissipar-seia elegendo o direito do autor em contruir seu personagem trágico. Mas por que Diadorim pertence à tragédia e não ao drama no qual o herói supera a si mesmo ensinando algo a seus leitores/espectadores? É preciso colocar em cena, neste ponto, que o corpo morto de Diadorim é uma figura fundamental do que as teorias políticas do século $X X$ (de Karl Shmitt e Walter Benjamin a Giorgio Agamben) vêm chamando de "mera vida" ou "vida nua". ${ }^{20}$ A mera vida natural sujeita à "matabilidade" 21 pelo poder. Núcleo originário do poder soberano (aquele que decide sobre a vida), mera vida seria o elemento que governa secretamente as ideologias da modernidade fundadoras de campos de concentração e dos genocídios que fazem a história da política como história da morte perpetrada pelo ser humano contra o ser humano. A tese a ser considerada nesse caso, seguindo a interpretação da biopolítica em Agamben e expandindo-a para uma interpretação do patriarcado, é de que esse se confunde com os Arcana Imperii elegendo a mulher como figura da matabilidade. O texto falocêntrico é sua arma simbólica. Diadorim, entre tantas outras, é confirmação desse paradigma políitico. Passemos a analisála por meio de tal viés, considerando que, como mulher/ morta, Diadorim é emblema da mera vida para então compreender a necessidade de sua matabilidade.

A propósito, Diadorim mesmo é quem dá a pista sobre sua condição de "mera vida": "Não posso ter alegria nenhuma, nem minha mera vida mesma, enquanto aqueles dois monstros não forem acabados". ${ }^{22}$ O que se confirma em Riobaldo: "Enquanto os dois monstros vivessem, simples Diadorim não vivia". ${ }^{23}$ Desse modo, qual a vida vivida por Diadorim? Que vida não era vivida? Em função de sua vida de jagunço, o que ele não tem é sua "mera vida" de mulher?

Diadorim é personagem trágico, e mais do que personagem, o "emblema trágico" que se sobrepõe ao "emblema jagunço" 24 no ato de sua morte. Sua morte tem caráter de transfiguração: ela passa do "emblema jagunço", definido em sua vestimenta, ao que chamarei de "emblema nu", o que significa que, mais do que desvelamento, é uma outra vestimenta que vem lhe definir desde que ela retirou sua "pele" de jagunço. 
${ }^{25}$ HANSEN, 2000, p. 131.

${ }^{26}$ ROSA, 1986, p. 530.
Pode-se dizer que é vestido de uma nudez de mulher na cena final, na inevitável leitura retroativa que o livro nos impõe, que se sabe também por retroação que Diadorim é "travestido" de jagunço. É como se Diadorim estivesse vestido de uma enganação, mas uma enganação nada gratuíta, já que é de homem/jagunço que ele se disfarça, se camufla para poder viver como homem, o que, na prática, Diadorim é. Isso nos permite pensar que Diadorim é tão homem, tão identificado com a sua condição de homem (Riobaldo se refere a ele sempre como "ele" ou simplesmente Diadorim), que podemos falar que ele se torna mulher apenas por um instante quando aparece morto. E, como mulher-morta, como que transformado em não-ser. Fato é também que ele só estaria enganando ao ser "mulher" como não poderia deixar de ser segundo a linha de demarcação dos atributos femininos na história das represetntações de mulheres. Fato é que seu corpo morto aparece como epifania e apoteose. Que sua aparição convoca ao cancelamento de qualquer pergunta como se uma resposta estivesse dogmaticamente em cena na equação que une morte/nudez/verdade: podemos assumir que um significante novo - o corpo de mulher morta - trouxe-nos um outro significado - o que era homem era falso e o que é muher é verdadeiro - e mantém a leitura patriarcal/logo/fono/falocêntrica que apaga o significante em nome de um significado, ou pensar que o significante revela-se em sua condição de escritura, em seu devir significante, revelação em si mesmo - o corpo morto é mulher revelada enquanto devir de um homem que, ele mesmo escritura, ele mesmo emblema, não deixa de ser homem ao longo do texto. O que implica que mulher revelada é tão verdade quanto o homem até então mostrado. Assim faria sentido a ideia de que Diadorim é "operador metalingüístico". ${ }^{25}$ Um operador, segundo Hansen, que se estabelece pelos jogos de sentido em que se expressa a passagem da designação à significação. Esta leiłura, no entanto, implica quebrar o pacto patriarcal rumo a uma leitura feminista sempre atenta ao modo como se representa uma mulher.

Duas hipóteses, nesse caso, devem ser consideradas: ou bem Diadorim é mulher e seu travestimento de jagunço é engano e sua nudez é verdade, ou, como é preciso levar em conta desde que essa roupa fora véu le o fim do livro não acaba exatamente em sua morte, o que também nos convida a continuar a pensar...), Diadorim não é exatamente mulher e sua roupa de jagunço coube-lhe muito bem. Diadorim não foi mulher durante todo o texto narrado, senão ao final e, mesmo assim, sob o signo da perplexidade e da sutileza, quando, então, precisamos redobrar a atenção ao discurso de Riobaldo. Riobaldo, ao ver o corpo morto, diz que "Diadorim era o corpo de uma mulher, moça perfeita". ${ }^{26}$ 
${ }^{27}$ ROSA1986, p. 157, grifo nosso
${ }^{31}$ ROSA, 1986, p. 87

32 ROSA, 1986, p. 92.

${ }_{33}$ ROSA, 1986, p. 134.
Nessa primeira frase ele trata de Diadorim como "o corpo de uma mulher", objetivando uma característica de seu amigo. A constatação vem na hesitação que opera o tempo da torção na própria ideia. Riobaldo segue em sentenças tão explicativas quanto marcadas pela surpresa: "Ela era". "Diadorim era uma mulher". "Diadorim era mulher como o sol não acende a água do Urucuia...". Percebendo a finura dessas declinações, Riobaldo demarca, ele mesmo, a pista: a distância entre Diadorim que ele conheceu como jagunço ("Meu corpo gostava do corpo dele....") ${ }^{27}$ e esse corpo revelado até que possa afirmar com certeza "Diadorim era mulher". É como se a dúvida (a "duvidação") não cessasse até que fosse preciso assumir esse fato cuja torção, naquele momento, é desfeita.

A pergunta "o que é ser homem?" cabe à relação Riobaldo-Diadorim, e não é apenas análoga à pergunta "o que é ser mulher?", à qual Diadorim não serve de resposta simples, mas entre elas há uma relação de copertencimento. Durante todo o romance Diadorim é menino e moço: "era um menino bonito, claro, com a testa alta e os olhos aosgrandes verdes". 28 "O moço, tão variado e vistoso, era, pois sabe o senhor quem, mas quem, mesmo? Era o Menino!". ${ }^{29} \mathrm{E}$ depois macho: "Eh, ele sabia ser homem terrível. Suspa!". ${ }^{30}$ Desse modo, percebe-se que a questão quanto ao fato de que Diadorim fosse "mulher" seria bem menos importante do que a questão de sua "desemelhança" " "Ele, o menino, era dessemelhante, já disse, não havia minúcia de pessoa outra nenhuma. [...] Eu queria que ele gostasse de mim". ${ }^{31}$ De sua "diferença": "Sou diferente de todo o mundo. Meu pai disse que eu careço de ser diferente, muito diferente". ${ }^{32}$ De seu caráter "singular". ${ }^{33}$

Diadorim vestido de homem, com sua vida de jagunço, é emblema da diferença, por oposição a seu corpo morto, emblema da identidade à qual ele é devolvida na forma de mulher morta. Essa mulher/morta é como que a vítima da racionalidade identificatória, devoradora da diferença, própria do padrão patriarcal. A esquizofrenia da razão está sempre lançada sobre Diadorim em todo o discurso de Riobaldo. Morta, ela encarna a impossibilidade de que uma mulher exista no mundo masculino. Ao voltar à condição de mulher, ela não existe senão como corpo morto. Tal é o que chamaremos de destino, não escolha, e destino é, para uma mulher, estar condenada à sua zoé, proibida de participar da vida qualificada dos homens, do bíos. A razão patriarcal é, por princípio, pigmaliônica: constrói modelos de mulheres para amar e odiar e, de qualquer modo, assassinar. Constrói heteronomamente a essência da mulher que Diadorim mostra em sua inteira verdade de zoé, mera vida que aparece em sua matabilidade. Diadorim, 
34 Cleusa Passos, em "Diadorim: Dia da Lua" (2008), analisa Diadorim de um ponto de vista bem diferente. A autora rastreia no texto os sinais de feminilidade (discurso e comportamento) de Diadorim, antecipando em sua interpretação o saber sobre sua condição de "donzela" e, de certo modo, comparando-a às demais personagens (Nhorinhá, Otacília) numa prefiguração da disputa feminina por um homem, no caso Riobaldo.

${ }^{35}$ LORAUX, 1985, p. 12.

36 Daniel LINS, 1997, p. 129.

37 LINS, 1997, p. 129 sendo a própria leminiscata, é a duplicidade que se recusa a estancar seu processo no ser "mulher" e, por isso, só pode vivê-lo ao ocultar-se da heterodeterminação à qual será destinada e sacrificada.

Em termos ético-políticos, o motivo pelo qual Diadorim será morta está ligado à insubmissão às regras da identidade. Ao fato de que ousou sair do seu papel de gênero, praticar a diferença em sua ação. A morte de Diadorim justifica-se, assim, na transgressão das regras, na queda na hybris que caracteriza o herói trágico sempre vitimado pelo destino que as mulheres de GSV não ousam combater: permanecem no papel que lhes concerne, seja o de prostituta, o de esposa, seja o de noiva. ${ }^{34}$ Essa regra, a de ser mulher, envolve um papel: uma vestimenta, um comportamento. Diadorim usou outra roupa e agiu de outro modo transcendendo o papel a que tinha sido destinada por certa anatomia, assim, teve que pagar com a vida, na "matabilidade" da "mera vida" contra a qual ela tinha se colocado ao ser "outro" que apenas mulher.

A encenação da morte, o fato de que ela se torne visível, é a chance, diz Loraux, ${ }^{35}$ de pensar a diferença dos sexos, o que vale especialmente para o caso de pensar a diferença sexual em Diadorim cuja vida é dividida em dois momentos: vida qualificada (homem e vestida) e vida desqualificada (mulher e morta). Que a revelação de sua condição de mulher se dê no instante de sua morte coloca em cena esse significante histórico que desde Aristóteles divide a política em dois territórios: ao homem cabe a vida, vestido de guerreiro lutando pela liberdade o homem é a vida qualificada que os gregos chamavam de bios e que se relacionava à experiência da pólis. À mulher cabe a morte, a nudez, a imobilidade da mera vida que os gregos chamavam de zoé e que diz respeito à experiência do Oikos ao qual também Diadorim é devolvida quando morta e encomendada pela curiosa figura da mulher de Hermógenes que Rosa grafa como a Mulher, com M maiúsculo, conforme falaremos mais adiante. Noutro sentido, sua condição matável, de res, mera vida, permanece em outra chave. Daniel Lins, interpretando o cangaço, oferece mais um aspecto que devemos trazer para a compreensão da imagem de Diadorim. Trata-se do "encontro marcado com a morte" 36 com o qual podemos pensar a luta de Diadorim com o próprio Hermógenes. Analisando o que ele chama o aspecto "western americano" do duelo do filme $O$ cangaceiro, de Lima Barreto, ele cria a tese de que "a conquista do feminino só pode terminar com o encontro marcado com a morte" como "tributo a pagar, antes do encontro final, do face a face entre os homens, como última cumplicidade" ${ }^{37}$ Lins coloca em cena a questão da "territorialidade masculina, fora do alcance das mulheres" 
${ }^{38}$ LINS, 1997, p. 67.

${ }^{39}$ ROSA, 1986, p. 16. que deve aqui ser considerada na interpretação da necessidade de matar Diadorim, ou de representar Diadorim como mulher apenas quando morta. Pois na luta com Hermógenes Diadorim ainda é homem. Se a entrada da mulher no cangaço mudou o destino de algumas sertanejas, ${ }^{38}$ se Lampião subverteu a ordem ao "ignorar a tradição" promovendo uma "revolução feminina" do cangaço, Diadorim, contudo, podendo pertencer a ele apenas na figura do "guerreiro" ocultando sua condição de mulher, não será parte dessa revolução. Diadorim, nesse caso, não conquistou o feminino, ele foi apenas a forma com que ele pode ser mulher.

\section{Homo sacer: travestimento indisponibilidade do corpo}

Que não se permita engano e se repita a pergunta: que motivo há para se matar essa mulher além de salvaguardar a tragédia como relação humana com a morte, sempre dependente do final infeliz na catástrofe do percurso de seus heróis? Tal pergunta acoberta outra mais curiosa e capaz de nos oferecer soluções menos superficiais: por que a morte de uma pessoa como Diadorim se dá como espetáculo de seu corpo? Por que seu segredo - no caso, um segredo sexual e corporal - é dito apenas na morte que culmina com sua nudez? Morte/nudez/mulher, eis a tríade que revela a verdade da cena que estamos tentando entender. Diadorim é a vítima daquilo que Loraux entendeu como reposição do papel feminino ao seu posto de coisa doméstica. Reposição que se dá por meio da revelação de um segredo - feito verdade - capaz de refazer o sentido inteiro da história. Que o segredo de Diadorim esteja marcado em seu corpo e que essa marca seja sua condição de mulher - em que o sexo é marca - é o que o final do livro, como toda a tradição patriarcal, não deixa de referendar. Tal segredo é a redução de uma mulher ao seu corpo - e esse corpo a cadáver. Emblema da matabilidade da mera vida.

Diadorim não protagonizou sua própria história senão pela vontade da fala de Riobaldo. Na condição de "neblina", ${ }^{39}$ ela é ofuscamento, como um objeto cuja característica é não chegar a uma forma definitiva. Objeto que escapa enquanto objeto e que só será capturado quando imagem de um corpo morto, momento em que se faz objeto total, o corpo-cadáver que interessou ao paradigma racionalista da ciência moderna baseada na relação sujeito-objeto, o mesmo que separa corpo e alma e que sustenta tanto o caráter da escritura quanto a leitura simbólica e metafisica da obra de Rosa. A mulher/morta é a mulher-objeto que, no senso comum, há muito virou piada. 
${ }^{40}$ Uma visão nova que vem mostrar a inversão do sentido da produção simbólica em que mulheres matam homens aparece no texto de Maria Cecília de Miranda Nogueira Coelho, intitulado "Banhos de sangue femininos: reflexões sobre um topos".

41 Walnice Nogueira GALVÃO, 1998.

${ }^{42}$ O capítulo "O par escamoteado" do livro A donzela-guerreira, de Walnice Nogueira Galvão, fornece-nos o argumento que permite inscrever Diadorim na linhagem de Palas Atena. Galvão fala de "uma imaginária partenogênese masculina" que cabe bem à figura de Diadorim, filha de um pai sem mãe, de um pai que, como Diadorim, aparece como virgem (ver p. 139-144).

${ }^{43}$ ELIADE, 1999, p. 77

${ }^{44}$ Conceito desenvolvido por Nicolaus Cusanus a partir de uma vasta tradição que envolve a filosofia desde seu nascedouro, propõe que se a pense a partir do que ele chama uma "fase présistemática do pensamento", ou seja, que se analise a fase préhistórica do princípio quando ainda não tinha sido filtrado pelo logos racionalizante. Mais teológico que filosófico, ou filosófico no lugar onde a razão se ocupa da fé e suas manifestações antropológicas, a coincidentia oppositorum é, segundo ele, a tentativa da totalidade que seria a forma da realidade última. Tal realidade última à qual podemos nos referir, como Eliade, pelo termo alemão Grund é "discernível unicamente enquanto mistério e paradoxo" (ELIADE, 1999, p. 82).

${ }^{45}$ ELIADE, 1999, p. 82.

46 UTÉZA, 1994, p. 367.

${ }^{47}$ ELIADE, 1999, p. 124
Na prática, ela é oposição a um homem-sujeito. O par Riobaldo/Diadorim é o par sujeito/objeto. Tal conceito de mulher-objeto é explicativo de uma longa história de gênero que a literatura tanto ajuda a construir como, apenas tardiamente, começa a verificar. ${ }^{40}$

Na tentativa de compreender a necessidade da morte de Diadorim, observamo-lo sob certos ângulos. A questão da vestimenta relaciona-se à androginia. Observada de um ponto de vista político, a androginia de Diadorim corresponde ao homoerotismo de Riobaldo do qual ele é rendido no ato mesmo da devolução de Diadorim à casa e à condição de mulher pela morte. A morte é, nesse caso, o caminho por onde a aliança entre gênero e natureza se refaz para alguém que, mera vida matável que ousou transgredir uma regra, precisa ser incluso no lugar da vítima, ou seja, na imagem da mulher/morta. Mas é possível pensar ainda um pouco mais sobre essa armadura que oculta seu corpo de mulher: travestida de jagunço, a "Donzela Guerreira" 41 - Atena aviltada ${ }^{42}$ - poderá entrar no bando dos jagunços, fazer "bando" com eles e participar assim da vida política que sua condição de "mera vida" ou "vida nua" não permite.

Antes, no entanto, devemos nos ater a um aspecto. Mircea Eliade, em Mefistófeles e o andrógino ou o mistério da totalidade, ${ }^{43}$ trata da coincidentia oppositorum, ${ }^{44}$ aspecto presente em todos os mitos e ritos que, por meio dela, "ensinam aos homens que a melhor via para se aprender Deus ou a realidade última é renunciar [...] a pensar e imaginar a divindade em termos de experiência imediata". ${ }^{45}$ Se Diadorim é realmente uma apresentação da coincidentia, não devemos ver nela apenas a mulher morta, mas o símbolo de alguma coisa transcendente. É o que faz, por exemplo, Utéza, ${ }^{46}$ cuja leitura interessantíssima, baseada nas correntes esotéricas presentes em Grande Sertão, vê na morte de Diadorim a revelação da alma de Riobaldo. O corpo morto seria essa "alma", e a morte de Diadorim poderia ser pensada em termos de sacrifício pelo qual a alma de Riobaldo é liberada de sua condenação. Minha intenção não é simplesmente descartar a leitura simbólica. Mas é preciso pensar que essa leitura, ela mesma, escamoteia na direção de entender o caráter biopolítico - e, nesse sentido, patriarcal - da própria literatura enquanto também ela é cálculo sobre a vida das mulheres, enquanto faz delas o emblema da "vida nua". Para isso é preciso levantar o elemento da mera "matabilidade" no lugar de um "sacrifício" da vida nua presente no viés profano da obra. Em outras palavras, a intenção desta leitura é determinar que assim como Diadorim é mais do que mero corpo, ele não deixa de ser esse corpo que aparece morto e, assim, é alçado à abstração meta-histórica, entra no mundo transcendental ${ }^{47}$ enquanto morre para a história. 
${ }^{48}$ AGAMBEN, 2002, p. 79-81.

${ }^{49}$ NANCY citado por AGAMBEN, 2002, p. 66.
Diadorim é sagrada tanto no sentido de que é intocável em vida (enquanto jagunço) quanto intocável quando morta justamente porque morta. A sacralização de Diadorim tem o sentido do homo sacer - a figura do condenado ao banimento (a ser abandonado) do direito romano. ${ }^{48}$ Sacer é aquele que é "sacralizado", tornando-se intangível pela lei e ao mesmo tempo submetido à lei de exceção (à lei fora da lei à qual é abandonado: Diadorim é "abandonada", como afirma Nancy: "abandona-se sempre a uma lei", ${ }^{49}$ ou seja, lançada para fora de qualquer relação): ser matável por qualquer um. O disfarce de androginia de Diadorim evita ao longo do texto que ele seja tocado, ao mesmo tempo que permite sua participação no "bando" dos jagunços (e não pertencer a homem nenhum), sob a forma de uma lei soberana que ele dá - enquanto não sabemos que ele é ela - a si mesmo. Bando, por sua vez, é a condição biopolítica daqueles que, tendo sido banidos, ao mesmo tempo encontraram um lugar, são incluídos pela exclusão, o que explica bem a condição de Diadorim. Se a morte se justapõe à nudez e define a sacralização (mera vida), a vestimenta relaciona-se à vida e à participação no bando enquanto ele é a vida qualificada em relação à mulheres, embora seja mera vida em relação ao governo e à polícia. Diadorim é, nesse sentido, duplicidade do sexo e da própria vida. Figura do bando, enquanto revelação da lei enquanto "estado de exceção".

Lei que é disfarçada de destino a ser cumprido e que impõe que Diadorim seja vítima de sua própria "soberania". De jagunço vestido a cadáver, ele é excluído pela lei masculina que ele mesmo usou para ocultar seu corpo de mulher - o emblema masculino do jagunço com o qual fez pacto. Dele dependia a saída da vida (enquanto zoé) e participação da vida da pólis. A liberdade pela qual Diadorim desejava lutar foi a mesma que faltou às mulheres para que pudessem historicamente dispor de seu corpo. Justamente o que foi possível a Diadorim enquanto jagunço e homem. Como mulher, no entanto, Diadorim restou como o camponês do conto Diante da Lei, de Kafka. Ele não pôde entrar como mulher na vida dos jagunços enquanto esteve sempre dele incluída enquanto excluída.

A indisponibilidade do corpo, contudo, é o que vem definir o lugar de uma mulher: só tem a si mesma quando morta, ou seja, jamais tem a si mesma. Num contexto patriarcal sua morte se dá justamente no âmbito em que ela não podia sequer identificar-se a si mesma. Assim é que a representação da morte de Diadorim pode ser interpretada como questão do autoconhecimento de Riobaldo, mas por outro ponto de vista é apenas derrota de Diadorim, que jamais pôde dispor de si mesma. 
${ }^{50}$ TIBURI e Bárbara VALLE, 2008, $\mathrm{p}$ 53.

${ }^{51}$ TIBURI e VALLE, 2008, p. 53.
O romance é marcado por um impossível que foi experimentado e é narrado por Riobaldo. Diadorim é, afinal, a que morre, e nessa morte tem toda a sua história de luta ainda que vença o Hermógenes - finalizada como uma derrota que permanece dialética. Ela venceu como jagunço, mas perdeu - e duplamente - como mulher. Mulher derrotada em sua luta para ser homem (afinal, Diadorim não decidiu mostrar sua nudez e dispor dela) e mulher que foi revelada, à sua revelia, como morta. Sua morte não é como a morte de qualquer jagunço, pois a narrativa deixa ver que ela morre para os jagunços homens que, imbuídos da sua condição de homens, ou seja, vivendo em grupo, a veem morta. Os jagunços a veem morta como anões que vissem Branca de Neve e chorassem a morte da donzela. ${ }^{50}$ Abandonada à Mulher (Rosa escreve essa mulher com M maiúsculo, substantivando-a como "A Mulher") de Hermógenesela mesma uma figura da enganação -, que lava e veste seu corpo morto no interior da casa (onde ela mesma esteve escondida e enganando ao próprio marido ao declarar que não gostava dele), Diadorim representa uma espécie de retorno do feminino ao feminino, do feminino ao lar, ao útero, ao oikos, após um grande exílio na pólis, território dos machos, e a guerra que nele se realiza. A casa é campo de concentração ao qual a "mera vida" é sempre confinada. ${ }^{51}$ Ainda que Diadorim possa ser interpretada em seu caráter mítico, em sua aparição iniciática, o fato de que ela encerre sob suas vestes um segredo não pode sugerir apenas a Vênus Urânia (a nua) que se esconde na Vênus Pândemos (a vestida), o princípio da beleza-verdade ideal sob as vestes reais: a carne, a roupa. A Mulher que dela cuida vem abrandar essa violência e operar a revelação. Mas também aquela, a Mulher, que operava a enganação do marido, vem desenganar a outra enganadora. Como o ladrão que rouba o ladrão. $O$ que se estabelece entre as personagens é um ato de comparação. A Mulher do Hermógenes representa a própria Vênus Pândemos, mundana e profana que vem revelar a Vênus Urânia sempre representada nua e que, ao estar vestida, engana. É algo da ordem de um segredo que a revela mulher, mas esse segredo não é revelado por ela mesma, senão sob a inevitável violência da qual ela é vítima.

\section{Réquiem para um jagunço transformado em mulher/morta}

A aparição do corpo morto de mulher poderia ser lida como algo fantástico. Diadorim teria sido assim encantado na forma de uma mulher. Porém, para além da brincadeira, Diadorim é, na verdade, alegoria da crise da 
identidade dos sexos em que o feminino aparece apenas como negativo. Diadorim mesmo não é esse negativo senão por ser objeto da fala de Riobaldo e, na hora de sua morte, como corpo-cadáver, objeto no sentido de coisa dessubjetivada. De quem perdeu sua potência de sujeito, ou seja, sua autonomia, sua disponibilidade sobre si mesmo.

De Diadorim também podemos dizer que ele tanto se torna mulher quando está morta quanto é negado como mulher ao estar morta, posto que a mulher/morta é já a mulher negada. E que essa morte é só o desfecho de uma vida em que Diadorim mesmo se negou como mulher. A negação é simbolicamente uma morte. Diadorim, como homem que foi, foi ao mesmo tempo sempre uma mulher negada e, nesse aspecto, morta. Falamos aqui de conceitos, sem apego a qualquer ideia de natureza revelada. Porque uma mulher se torna homem - ser que vive livremente na vida pública ao negar-se como mulher. A vida pública é "coisa de homem" e implica a morte da mulher. Dentro de casa, por sua vez, a morte é sempre "coisa de mulher".

Nesse caso, Diadorim como mulher estaria morta desde o começo: o emblema da mulher/morta, a revelação que obriga a retornar e reler o romance, pode mesmo valer como verdade em um nível metalinguístico e simbólico, mas não no sentido de uma mulher viva vestida de jagunço, e sim de um jagunço que ocultava uma mulher enquanto revelava uma não-mulher. Na experiência de sua vida espelhada na ordem à qual busca pertencer, Diadorim seria posta em crise da sexualidade, nem homem, nem mulher, mas antes nãomulher enquanto homem e não-homem enquanto mulher; homem-travestido-vivo por oposição à mulher-nua-morta. Ainda que, ao final, no tempo da morte, seja, de repente, mulher que - ao se revelar morta - se revela também a enganação como potência da mulher e a negação de sua corporeidade de mulher. Essa que lhe permitia justamente ter outro tipo de vida do que aquele que "caberia" a uma mulher. Diadorim é, assim, a mulher como aparição - corpo morto, fantasma de um passado não revelado, escamoteamento da verdade que se dá a ver como num susto em que "às

${ }^{52}$ HANSEN, 2000, p. 131 claras dá-se o oposto". ${ }^{52}$ Como tal, a mulher aparecida de entre as vestes do homem é o que assusta não apenas porque um desejo estaria agora autorizado a ter se realizado no passado, mas porque o próprio desejo homosexual uma vez reconhecido, posto debaixo de nossos olhos de leitores, exposto na fala explícita de Riobaldo, na verdade, não poderia jamais ter sido realizado.

Eis que então a mulher é morta mesmo que ela tenha sido sempre um homem. Em termos patriarcais, para começo de conversa, é no texto que uma mulher tem que morrer, se uma mulher estiver ali na condição de heroína é, mais cedo 
ou mais tarde, como morta que ela aparecerá. Literatura é, nesse sentido, aspecto do velho projeto biopolítico enquanto cálculo que o texto como forma de poder faz sobre a vida, sobre o corpo, sempre subjugado ao valor do patriarcado e do sexismo que lhe é próprio. O romance de Rosa, em que pese a sua simplesmente absoluta genialidade, dá ganho de causa à tradição da literatura como discurso biopolítico do patriarcado cuja desmistificação é tarefa urgente da crítica feminista.

\section{Referências}

AGAMBEN, Giorgio. Homo Sacer: o poder soberano e a vida nua I. Belo Horizonte: UFMG, 2002.

Ninfe. Torino: Bolatti Boringuieri, 2007.

ALMEIDA, Leonardo Vieira de. Diadorim:( o pacto como emblema trágico do corpo. Disponível em: <http://www. filologia.org.br/ixcnlf/7/01.htm >. Acesso em: 7 nov. 2011.

BLAY, Eva Alterman. Assassinato de mulheres e direitos humanos. São Paulo: Ed. 34, 2008.

BUTLER, Judith. Problemas de gênero: feminismo e subversão da identidade. Tradução de Renato Aguiar. Rio de Janeiro: Civilização Brasileira, 2003.

COELHO, Maria Cecília de Miranda Nogueira. "Banhos de sangue femininos: reflexões sobre um topos". In: Filosofia: machismos e feminismos. Florianópolis: Ed. UFSC. No prelo.

DERRIDA, Jacques. Gramatologia. Tradução de Mirian Schneiderman e Renato Janine Ribeiro. São Paulo: Perspectiva, 2006.

ELIADE, Mircea. Mefistófeles e o andrógino. São Paulo: Martins Fontes, 1999.

FOUCAULT, Michel. História da sexualidade: a vontade de saber. Tradução de Maria T. C. Albuquerque. 13. ed. Rio de Janeiro: Graal, 1999. v. I .

GALVÃO, Walnice Nogueira. A donzela-guerreira: um estudo de gênero. São Paulo: SENAC, 1998.

GRUNSPAN-JASMIN, Élise. Lampião: senhor do Sertão - vidas e mortes de um cangaceiro. São Paulo: EDUSP, 2006.

GUILHEN, Ellen. ( A morte de Ofélia nas águas: reflexos da personagem de Shakespeare na poesia simbolista brasileira. Campinas, SP: [s.n.], 2008. Disponível em: <http://www.bibliotecadigital.unicamp.br/document/ ?code $=000436429>$. Acesso em: 7 mar. 2013.

HANSEN, João Adolfo. O o: a ficção da literatura em Grande Sertão: Veredas. São Paulo: Hedra, 2000.

LINS, Daniel. Lampião, o homem que amava as mulheres. O imaginário do cangaço. São Paulo: Annablume, 1997. 
LORAUX, Nicole. Façons tragiques de tuer une femme. Paris: Hachette, 1985.

MORAIS, Márcia Marque de. "'Coração mistura amores': o desejo deslocado nas veredas do Grande Sertão". In: FANTINI, Marli (Org.). A poética migrante de Guimarães Rosa. Belo Horizonte: UFMG, 2008. p. 91-112.

PASSOS, Cleusa. "Diadorim: Dia da Lua". In: FANTINI, Marli (Org.). A poética migrante de Guimarães Rosa. Belo Horizonte: UFMG, 2008. p. 64-88.

POE, Edgar Allan. "Filosofia da composição". In: Poesia e prosa. Tradução de Oscar Mendes e Milton Amado. Porto Alegre: Globo, 1960. p. 501-511.

ROSA, João Guimarães. Grande Sertão: Veredas. 29. ed. Rio de Janeiro: Nova Fronteira, 1986.

TIBURI, Marcia. "Ofélia Morta: do discurso à imagem". Revista Estudos Feministas, v. 18, n. 2, p. 301-318, maio/ago. 2008.

"Marias Bonitas: entre a mulher mítica e as mulheres reais, uma fratura no sertão". In: QUEIROZ, André. Arte \& pensamento: a reinvenção do Nordeste. Fortaleza: SESC, 2010. p. 111-125.

TIBURI, Marcia; VALLE, Bárbara. Mulheres, Filosofia ou coisas do gênero. Santa Cruz do Sul: EDUNISC, 2008.

UTÉZA, Francis. João Guimarães Rosa: metafísica do Grande Sertão. Tradução de José Carlos Carbuglio. São Paulo: EDUSP, 1994.

[Recebido em 22 de novembro de 2011 e aceito para publicação em 28 de maio de 2012]

\section{Diadorim: Biopolitics and Gender in the Metaphysics of the Sertão}

Abstract: Diadorim is the emblematic character of Guimarães Rosa, avatar of the female warrior, symbol of a strong sacrifice which we can affirm to be feminist, that one constructed in the denial of the feminine to live a freedom from the beyond-sex realm. The analysis of the character allows evaluating the relationship between body and power as foundation of the known history of the gender domination. We intend to present a feminist reading that permits to investigate the double side of the sexuality that involves Diadorim. Man and alive while dressed, woman and dead when undressed, Diadorim will be a part of an archetypal history, of the topos of the woman/dead. This dead woman is, therefore, "just life" or "naked life" which appears in the contemporary biopolitical analysis. The crossing of feminism and biopolitics is the reading method of the work. It will lead us to see that the function of the textuality of the patriarchy is both enjoy over a woman's dead body and return her to her presumed domestic and antipolitical nature.

Keywords: Feminism; Diadorim; Biopolitcs; Sertão. 